UDK 811.163.42’373.45:355.1(091)

Izvorni znanstveni rad

Rukopis primljen 8. III. 2021.

Prihvaćen za tisak 31. V. 2021. doi.org/10.31724/rihjj.47.2.8

\author{
Dalibor Vrgoč \\ Hrvatsko vojno učilište „Dr. Franjo Tuđman” \\ Ilica 256b, HR-10000 Zagreb \\ orcid.org/0000-0002-6259-0187 \\ dalibor.vrgoc@morh.hr
}

\title{
DOMOBRANSKA ČASNIČKA ELITA KAO SUSTVARATELJICA VOJNOGA NAZIVLJA
}

U radu se propituju dosadašnje znanstvene spoznaje o početcima službene izgradnje hrvatskoga vojnog nazivlja iz druge polovice 19. stoljeća, u prvome redu o jedinstvenosti uloge Bogoslava Šuleka kao njegova utemeljitelja. Istraživanjem primarnih izvora dokazuje se da Šulek, premda stožerna figura vojnoterminografskih nastojanja, nije bio jedini stvaratelj hrvatske vojne riječi. Proučavanjem arhivske građe u Zagrebu i Beču na vidjelo izlazi niz autora, koji su u jeku ustrojavanja domobranstva prevodili vojne priručnike na hrvatski jezik. Štoviše, uz brojne naslove vojnostručne literature, objavili su i dva pionirska vojnojezična priručnika. Autori su redom pripadali domobranskom časničkom predavačkom kadru, tako da je Šulek među njima bio jedina nevojna osoba. Nova konfiguracija zaslužnikâ izgradnje hrvatskoga vojnog nazivlja otkriva da su se neki važni naslovi dosad pogrešno pripisivali Šuleku, no i upućuje na nove spoznaje o opsegu Šulekova opusa te dostupnosti njegovih naslova. Usporedbom časničkih prijevoda s onima Bogoslava Šuleka upotpunjuje se mozaik jezične koncepcije izgradnje hrvatskoga vojnog nazivlja.

\section{Uvod}

Ovim se radom nastoje produbiti dosadašnje znanstvene spoznaje kad je riječ o povijesti hrvatskoga vojnog nazivlja, u prvome redu njegovu službenome ustrojavanju u 19. stoljeću. Vojno je nazivlje važno pozicionirati u odnosu na druga nazivlja kako bi se razumjela i njegova izvanjezična posebnost i simboličko-identitetska vrijednost. U tome smislu indikativna je tipologija nazivljâ koju je 
predložio Radoslav Katičić (1999), pri čemu, uz zakonsko i upravno, izrijekom navodi vojno nazivlje kao ,službeno nazivlje”. Ono se, prema Katičiću, mijenja promjenom vlasti i državnoga uređenja te je podvrgnuto strogu propisu. To nas uvodi u sav sjaj i tragiku sudbine hrvatskoga vojnog leksika koji su započeli upravo njegovim oslužbenjivanjem po ustrojenju Kraljevskoga hrvatskog domobranstva 1868.

Opće je mjesto jezikoslovne literature da je Bogoslav Šulek, istinski polihistor, no iznad svega strastveni jezikoslovac, leksikograf i terminolog koji je zadužio hrvatsku terminologiju izgradnjom nazivlja mnogih struka (Horvat i Mihaljević 2019: 51-52), utemeljitelj i hrvatskoga vojnog nazivlja. ${ }^{1}$ Horvat i Mihaljević opravdano ga ubrajaju $u$,,najsvestranije hrvatske znanstvene i kulturne djelatnike 19. stoljeća”, koji je „svestrano radio na stvaranju hrvatskoga znanstvenog, stručnog i vojnog nazivlja te utjecao i na to da ,hrvatski jezik doista postane diplomatički, odnosno jezik državnih i javnih poslova te jezik znanosti i obrazovanja" (Horvat i Mihaljević 2019: 47). Kad govorimo o avangardnosti Šulekovih terminoloških usmjerenja, Vraneša i Petrović pomno razrađujući Šulekova metodološka načela za usustavljivanje nazivlja naglašavaju u kojoj mjeri „dio njegova izuzetno plodonosnoga opusa i dalje intrigira svojom recentnošću” (Vraneša i Petrović 2016: 130), dok Hudeček i Mihaljević uočavaju kako je Šulek „,imao veoma jasnu i modernu ideju o terminološkome normiranju” (Hudeček i Mihaljević 2019: 5).

Okrenemo li se temi rada, odnosno vojnomu nazivlju, Gostl u svojoj antologijskoj studiji o Šuleku krajnje plastično pridodaje kako ni rečeno ustrojavanje domobranstva 1868. „nije mimoišlo Šuleka” (Gostl 1996: 29), odnosno „hrvatska se vlast opet sjetila Šuleka" (Martinčić 2020: 130). U razdoblju od 1870. do 1875. on prevodi i izdaje niz službenih vojnih priručnika s mađarskoga jezika čiji je „,terminološki repertoar njihovim objavljivanjem i uporabom kodificiran te time postao onodobnim službenim hrvatskim vojnim nazivljem" (Vrgoč 2020a). ${ }^{2}$ Šulek je prijegornim vojnoterminografskim radom oblikovao hrvatsko vojno

\footnotetext{
1 Za minucioznu razradbu nazivlja prema strukama i pripadajućim djelima iz Šulekova opusa više v. u Horvat i Mihaljević (2019).

2 Zasluge Šuleka za nazivlje raznih znanstvenih disciplina i struka, pa tako i vojne, nevjerojatnih su razmjera, usp. Vraneša i Petrović (2016: 130). Štoviše, uvidom primjerice samo u Naredbenik za kraljevsko hrvatsko-ugarsko domobranstvo, koji je objavljivan kroz četiri godine te obaseže gotovo 750 stranica u petnaest svezaka formata $22 \times 14 \mathrm{~cm}$, stječe se zorna slika monumentalnosti njegovih terminoloških napora (Vrgoč 2020a: 155).
} 
nazivlje izgradivši ga time kao samostalan podskup općejezičnoga fonda, snažno pridonijevši razvoju polifunkcionalnosti hrvatskoga jezika (usp. Samardžija 2019: 31).

Ostaje neospornim da su, s jedne strane, Šulekove zasluge za nazivlje raznih znanstvenih disciplina i struka, pa tako i vojne, impozantnih razmjera. Čak i da je sve ostalo na njegovim dvama rječnicima - Němačko-hrvatskome rěčniku iz 1860. i Hrvatsko-njemačko-talijanskome rječniku znanstvenoga nazivlja iz 1874./1875. - dostajalo bi građe gotovo dovoljno za izgradnju sveukupnoga onodobnog hrvatskog vojnog nazivlja (Vrgoč 2020a: 151). S druge strane, ovim će se istraživanjem rasvijetliti još neistražena područja službenih vojnoleksičkih nastojanja pojedinih Šulekovih suvremenika, koji su ostali u sjeni toga jezikoslovnog velikana. Riječ je o nizu domobranskih časnika koji su se sve do danas nalazili na marginama suvremene znanstvenoistraživačke optike ili su joj, po svoj prilici, jednostavno promicali.

Ovaj će rad biti posvećen zaslužnicima sustvaranja hrvatskoga vojnog nazivlja u jeku njegova ustrojavanja i njihovim prevoditeljsko-terminografskim ostvarenjima, koja se ovim istraživanjem, po svemu sudeći, prvi put objelodanjuju znanstvenoj i široj javnosti. Namjera je predočiti vojnoterminografska djela dokumentirana u arhivima u Beču i Zagrebu, ponuditi što iscrpniju biobibliografiju njihovih autora te ih kontekstualizirati u odnosu na onodobna intenzivna filološka strujanja, s osobitim osvrtom na djela dosad pripisivana Bogoslavu Šuleku.

\section{Pogled u donedavna teorijsko-povijesna uporišta i najnovije spoznaje}

Hrvatsko je vojno nazivlje sve donedavna u literaturi bilo tematizirano uglavnom u nekoliko osvrta, radova ili poglavlja u knjigama mnogo širega opsega (Vince 1990; Horvatić 1995; Pranjković 2006; Samardžija 2004, 2008; Mamić 2007, 2008; Horvat, Hudeček i Mihaljević 2015; Ham 2016, 2017). Redovito su predmetom znanstvenoga zanimanja bili odsječci iz povijesti postanka vojnoga nazivlja, najčešće „domobranskoga”, ili se panoramski prikazivao njegov razvoj od 19. stoljeća do danas. Poviješću hrvatskoga vojnog nazivlja bavi se i jedna disertacija na njemačkome jeziku, no riječ je o dijakronijskome presjeku na razini 
evidentiranja leksika i njegova povijesno-političkoga konteksta i izvanjezičnih utjecaja, a ne o njegovoj iscrpnoj lingvističko-terminološkoj raščlambi (Orešković 2010).

No, kad je riječ o tome koliko duboko u povijest sežu leksikografskoterminografska nastojanja oko vojnoga nazivlja, u jednoj od posljednjih studija razrađuje se i predlaže redefiniranje uvriježeno prihvaćenoga vremenskog raspona njegova postanka (Vrgoč 2020b). Naime, svoje mjesto u impozantnome leksikografskom opusu Ivana Tanzlinghera Zanottija (1651. - 1732.) našao je i aneksni vojni rječnik, ${ }^{3}$ koji Vrgoč prepoznaje kao ozbiljan pionirski pokušaj oblikovanja hrvatskoga vojnog nazivlja prikladan, dakako, onodobnim terminološkim potrebama. ${ }^{4} \mathrm{U}$ zaključku istraživanja toga premda nevelikoga, no važnoga leksikografskog djela, Vrgoč Tanzlinghera i njegov rječnik ovjenčava naslovom „,praoca hrvatskoga vojnog nazivlja”, odnosno ,prvim hrvatskim vojnim rječnikom" (Vrgoč 2020b: 447).

Ipak, u literaturi se redovito kao stožerna inajprepoznatljivija figura nazivotvornih pregnuća u izgradnji vojnoga nazivlja ističe ime njegova utemeljitelja, Bogoslava Šuleka. Njegove vojnoterminografske i vojnoterminološke zasluge za hrvatski su jezik bez presedana. O tome, među ostalim temama, piše i Ivan Martinčić u svojoj nedavno objavljenoj opsežnoj i slojevitoj monografiji o djelu i djelovanju Bogoslava Šuleka (Martinčić 2020). Dosad se u literaturi ustrajavalo na činjenici proizišloj iz Šulekove osobne korespondencije i zapisâ da je na molbu tadašnjega zapovjednika Kraljevskoga hrvatskog domobranstva, generala Miroslava Kulmera, s mađarskoga jezika preveo ,vojničke zapoviedke”, preciznije ,za kratko vrijeme do 20 takovih knjižica" (Torbar 1896: 176). Gotovo redovito bi se ti podatci prenosili posredno, iz sekundarnih izvora, ponajprije Josipa Torbara kao sročitelja nekrologa posvećenog Šuleku, njegove svojevrsne biografije, te iz obilja antologijskih podataka Zlatka Vincea (Vince 1990: 563). ${ }^{5}$ Jednako tako,

\footnotetext{
3 Tanzlingherov rukopisni vojni aneksni rječnik Raccolta d'alcuni termini militari che s'attrovano sparsi nel Libro Maresciallo datira s prijelaza 17. u 18. stoljeće, a od 1836. godine čuva se u Knjižnici Britanskoga muzeja (British Museum Library) u Londonu i donosi oko 380 hrvatskih vojnih naziva, kolokacija i fraza, a nalazi se priložen opsežnomu Tanzlingherovu rječniku, tzv. londonskomu rukopisu, jednomu od četiriju poznatih.

4 Uzevši općenito izgradnju hrvatskoga nazivlja, stručnjaci uglavnom ističu polovicu 19. stoljeća kao njezin početak. Više o tome v. u Hudeček i Mihaljević (2019: 4) te u studiji o povijesti nazivlja u hrvatskome jeziku Horvat, Hudeček i Mihaljević (2015: 301-355).

5 Misli se na kapitalnu knjigu Zlatka Vincea o društveno-političkoj povijesti hrvatskoga jezika koja je doživjela tri izdanja, Putovima hrvatskoga jezika.
} 
sekundarnim se izvorima za određeni broj njih može utvrditi kojih je točno naslova Šulek bio autorom. Naime, Maixner i Esih (1952) donose iscrpan popis Šulekove bibliografije radova, prema kojoj Šulek u Plodovima moga pera, ${ }^{6}$ među ostalim svojim djelima, manu propria popisuje naslove vojnih priručnika kojih je bio prevoditelj s mađarskoga u razdoblju od 1870. do 1874. (Vrgoč 2020a: 151). Budući da Šulekov popis datira iz 1874., ostaje otvorenim pitanje je li Šulek i nakon te godine nastavio s prijevodima za domobranstvo i time još osjetnije zadužio povijest hrvatskoga nazivlja. Rekonstrukcijom Šulekove osobne korespondencije s Petrom Preradovićem i oslanjajući se na spomenuti vlastoručni Šulekov popis, Martinčić broj prijevodnih knjiga svodi na $26,{ }^{7}$ a Šulekovo okončanje rada na njima i objavljivanje smješta u 1874. (Martinčić 2020: 131).

Svi podatci o Šuleku više od stoljeća stalnica su znanstvenoistraživačke literature onkraj koje se gotovo nije ni zalazilo te se perpetuiraju u svim radovima u kojima se u većoj ili manjoj mjeri promišlja o nazivlju vojništva. Jednako tako, smatralo se da je većina Šulekovih vojnojezičnih naslova zagubljena (Martinčić 2020: 129-135). Stoga su njegovi proučavatelji uglavnom po refleksu morali posezati za sekundarnim, fragmentiranim izvorima i time bili prikraćeni za dragocjenost autentičnosti i, u Šulekovu slučaju, raskoši primarnoga izvora pri istraživanjima. Ipak, ovo istraživanje svojevrsni je iskorak iz ustaljenih znanstvenih spoznaja jer se njime dokazuje da Šulek nije stao na dosad utvrđenome broju od 26 priručnika, nego je objavio još nekoliko njih i nakon 1874. Jednako tako, dokumentiranim pretragama arhivske građe osporava se teza kako se priručnike „ne može vidjeti de visu” te kako se „stoga najviše i navode samo kao popisi, popisi nestalih” (Martinčić 2020: 130,133). Vidjet ćemo da je glavnina njih preživjela i nalazi se u nacionalnim arhivima.

S druge strane, još važnijom pokazat će se spoznaja da su mu se u literaturi neki od važnih priručnika pogrešno pripisivali te, premda stožerni, očigledno nije bio jedini stvaratelj hrvatskoga vojnog nazivlja. Već je jedno od posljednjih istraživanja ukazalo na postojanje predšulekovskih domobranskih priručnika koji nisu ostali samo na razini pokušaja (Vrgoč 2021a). Objavljeni su kao

\footnotetext{
6 Naslov Šulekova vlastoručnoga popisa njegovih djela do 1874. koji se čuva u arhivu HAZU-a (Maixner i Esih 1952: 34).

7 Martinčić na mjestima spominje i broj od 27 priručnika, no uvidom u pretisak popisa koji Martinčić donosi jasno je da je riječ o njih 26 .
} 
službeni priručnici u Vojnome Sisku i Zagrebu u razdoblju 1868. - 1874. Šest je naslova tada pod pseudonimom S. S. Kirinski s njemačkoga 'ponašio', odnosno preveo visoki domobranski časnik Stjepan pl. Šašić Kirinski (Vrgoč 2021b). ${ }^{8}$ Kao posljedica svih navedenih propitivanja, u radu se progovara o domobranskoj časničkoj eliti kao o Šulekovoj sustvarateljici hrvatske vojnojezične baštine.

Nesumnjivo je da bi bez Šulekove uloge kao najplodnijega nazivotvorca i njegova obilnoga vojnoterminografskog opusa hrvatsko vojno nazivlje bilo gotovo nemoguće i zamisliti. Ipak, s nekoliko najrecentnijih radova te sveobuhvatnim monografskim istraživanjem iz 2020. u kojemu se s terminološkoga motrišta pruža dijakronijsko-sinkronijski presjek hrvatskoga vojnog nazivlja (Vrgoč 2020a) upotpunjuje se mozaik njegova nastanka, razvoja i suvremenih kretanja. Štoviše, spomenuti radovi, u prvome redu, bacaju novo svjetlo na kronologiju njegova osmišljavanja i otkrivaju nove protagoniste njegove izgradnje. Ovo istraživanje nadovezuje se na njih nastojeći afirmirati zanemarene aktere toga procesa, a njihova djela predočiti u filološko-terminološkome svjetlu te ustanoviti korelaciju sa Šulekovim ostvarenjima. Na kraju se kao prilog objavljuje popis vojnostručne i vojnojezične literature objavljene u Hrvatskoj za potrebe ustrojavanja domobranstva.

U svakome slučaju, dosadašnji znanstvenoistraživački domašaji pokazuju se djelomice u raskoraku s najnovijim spoznajama ovoga istraživanja, stoga se ona ovdje izlažu u analitičkome razdjelu rada.

\section{Kontekst istraživanja i metodološki postupci}

Motivacija za daljnju i slojevitiju razradbu geneze hrvatskoga vojnog nazivlja proizišla je iz spomenutoga rada o domobranskome časniku, ,vojniku-učenjaku” Stjepanu pl. Šašiću Kirinskome (1822. - 1895.), posvemašnjemu anonimcu u jezikoslovnoj i općenito stručnoj literaturi, koji je prije Šuleka i istodobno s njim preveo na hrvatski jezik i objavio važne priručnike za ustroj domobranstva (Vrgoč 2021b). Štoviše, prema istraživanju primarnih izvora bio je u osobnome kontaktu sa Šulekom upravo radi terminoloških bistrenja (Vrgoč 2021a).

8 Više o tome v. u Vrgoč 2021a. 
Nadovezujući se na taj rad, ovdje su se lančano nametnula tri temeljna pitanja na koja će se nastojati odgovoriti:

1. Postoje li uz Stjepana pl. Šašića Kirinskoga dodatna domobranska vojnoterminološka ostvarenja iza kojih ne stoji Šulek kao prevoditelj?

2. Koji se naslovi neporecivo mogu pripisati Šuleku?

3. Jesu li Šulekovi prvotisci uglavnom nestali ili su dostupni proučavateljima njegova opusa?

Polazeći od tih propitivanja, namjera je prikladnim metodama doći do odgovora te utvrditi njihove eventualne učinke na dosadašnje teorijske, u prvome redu leksikografskopovijesne spoznaje. Šira metodološka strategija ovoga rada pripada kvalitativnomu i deskriptivnomu tipu istraživanja te jednim svojim dijelom komparativnomu, dok je arhivsko istraživanje bio temeljni metodološki alat dolaska do novih spoznaja. Pristup je podrazumijevao pretragu arhivskih i bibliotečnih fondova te proučavanje materijalne i digitalizirane građe (dokumenata, arhivalija, periodičkih publikacija) pohranjene u nacionalnim institucijama u Zagrebu i Beču te mrežno dostupnih austrougarskih vojnih almanaha, shematizama i godišnjaka. U konačnici, dosegnuti se rezultati predstavljaju, opisuju i kontekstualiziraju.

\section{Rezultati istraživanja}

\subsection{Službovnik i Vježbovnik plodovi pera podmaršala Ivana Vukovića ${ }^{9}$}

Činjenica opsežnosti i terminološke razrađenosti Šulekove vojnoterminografske građe te njegova leksikografskoga autoriteta nametala je u literaturi pretpostavku da je taj naturalizirani Hrvat preveo još neke ključne priručnike za domobranstvo i nakon 1874. Tako Vince (1990: 564), pozivajući se na nekrolog Josipa Torbara, u popis Šulekovih prijevoda uključuje opsežan i važan Službovnik za kr. ug. domobranstvo (I. i II. dio) iz 1875., sa zadrškom kako ne može „pouzdano reći da li je sve to preveo Šulek, ali će najveći dio biti njegov". Na istome tragu Pranjković (2006: 127) izrijekom spominje Službovnik misleći da „nema

\footnotetext{
9 U radu se navodi čin u kojemu je Ivan Vuković umirovljen.
} 
sumnje kako je Šulek preveo i Službovnik za kr. ug domobranstvo koji je u dva omašna sveska objavljen 1875. godine”, osnovano apostrofirajući da „bi se tim publikacijama trebalo posebno zabaviti”".

Međutim, ovim je istraživanjem utvrđeno da Službovnik (ukupno 600 stranica u dva sveska) ipak nije plod Šulekova pera. Možemo se složiti s Pranjkovićem (2006: 127) da Službovnik, dodajmo tomu i njegov autor, zaslužuju biti predmetom podrobnijega istraživanja. Ovdje će se stoga nastojati tematizirati temeljne filološke posebnosti toga prijevoda, na odabranome uzorku usporediti Vukovićev terminološki fond s onim u Šuleka i Šašića Kirinskoga te prema dostupnim podatcima ponuditi biografske podatke njegova autora.

Naime, 1875. iz Vienca doznajemo da je objavljen niz ,vojničkih knjiga”. Kod svih je naslova riječ o prijevodnoj literaturi te je u kratkim crtama navedeno o kojim je prevoditeljima riječ. Gotovo odreda su u pitanju domobranski časnici, a valja spomenuti da se i te godine u tome društvu našlo ime „dr. Šuleka”. Iz popisa doznajemo da je spomenuti Službovnik, ,prievod nadporučnika i profesora Vukovića u vojničkoj akademiji Ludovicejskoj u Pešti” (Vienac, br. 40, 2. listopada 1875.), a ne Šulekov, kako se to dosad pretpostavljalo. Štoviše ispostavlja se da je Vuković preveo i dvosvezačni Vježbovnik za kraljevsko ugarsko-hrvatsko pješačtvo, uz Službovnik jedan od temeljnih priručnika za netom ustrojenu vojsku, koji je kasnije bio predmetom znane Krležine persiflaže.

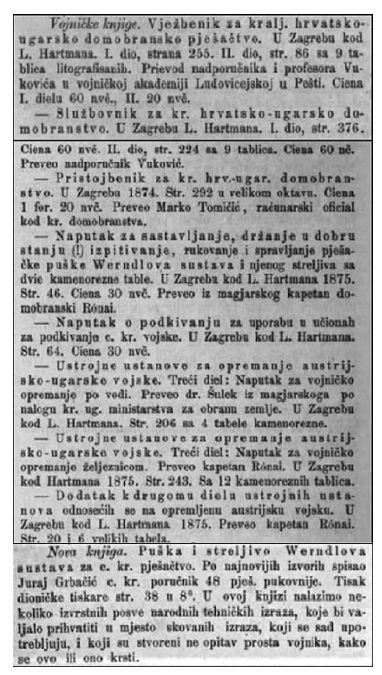

Slika 1. Rubrika iz Vienca o novim ,,vojničkim knjigama” (1875.) 
Biografski podatci o „nadporučniku i profesoru Vukoviću” oskudni su i razasuti po raznovrsnim izvorima, no u manjoj mjeri ipak dostupni. Riječ je o domobranskome časniku Ivanu Vukoviću ${ }^{10}$ (1846. - 1927.), u to doba jednome od hrvatskih nastavnika na netom osnovanoj Kraljevskoj ugarskoj domobranskoj akademiji Ludoviceum u Budimpešti (Horel 2015: 87), kasnije general-bojniku, a po umirovljenju 1904. titularnome podmaršalu (Schmidt-Brentano 2007). Rođen je u Drežničkome Selištu, a rodom iz sela Stajnica u brinjskome kraju. Istraživanjem je potvrđen i oblik s obiteljskim nadimkom, Ivan Vuković-Murković, vjerojatno zbog brojnosti nositelja prezimena Vuković (Tominac 2004). Podmaršali Radovan Grba (1849. - 1918.) i Ivan vitez Tomičić uvrštavaju ga, i prate portretom, među 230 hrvatskih generala kroz povijest u jubilejnoj knjizi objavljenoj 1908. povodom 60-godišnjice vladavine Franje Josipa Za kralja i dom.

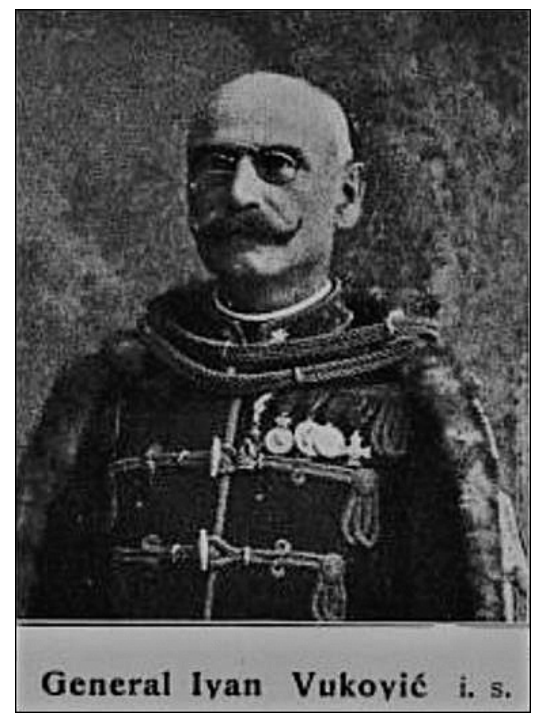

Slika 2. Podmaršal Ivan Vuković prevoditelj Službovnika (1875.) i

Vježbovnika (1875.)

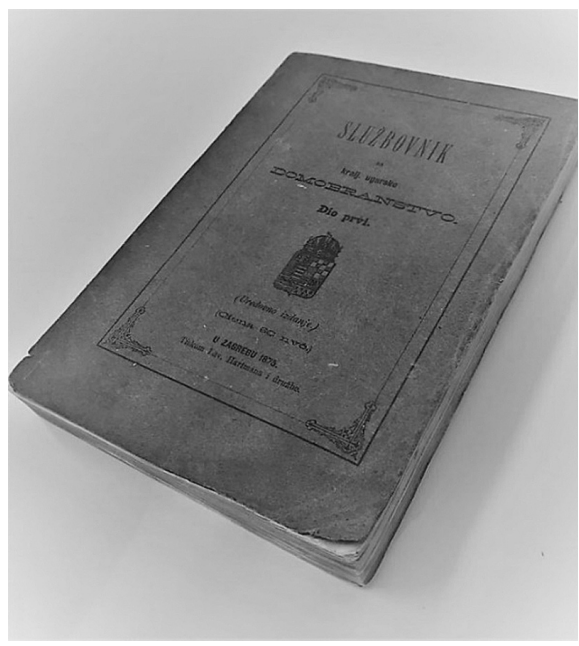

Slika 3. Prvotisak Službovnika za domobranstvo (1875.)

[C zbirka autora]

Budući da se priručnik dosad smatrao Šulekovim prijevodom, važno je progovoriti ovdje o njegovim jezičnim posebnostima, staviti ih u suodnos s njegovim drugim

\footnotetext{
10 Istraživanjem je potvrđen i oblik s obiteljskim nadimkom, Ivan Vuković-Murković, vjerojatno zbog brojnosti nositelja prezimena Vuković.
} 
izdanjem te ih kontekstualizirati u odnosu na pouzdana Šulekova djela, no i ona Šašića Kirinskoga. Za komparativni prikaz pokazuje se ključnim činjenica da je Službovnik prethodno prvomu izdanju 1875. doživio i djelomična izdanja (Izvadak iz Službovnika ${ }^{1} 1868 .,{ }^{2} 1868 .,{ }^{3} 1874$.), za čije je prijevode zaslužan Stjepan pl. Šašić Kirinski. Naime, supostavljanjem dvaju priručnika sinoptički se daju izvrsno usporediti podudaranja i razlike Vukovićeva i prijevoda Šašića Kirinskoga. Rezultati komparativne raščlambe na uzorku daju mogući odgovor na nastanak Vukovićeva prijevoda. S druge strane, u namjeri da se terminološki korpus Službovnika jednako tako usporedi sa Šulekovim nazivljem, moralo se posegnuti za srodnim, no tematski drukčijim priručnicima (konjaničtvo, sipačari, obkopari itd.) te pretragom locirati Šulekove korelate. U Tablici 1 supostavljaju se Šulekova, Vukovićeva i rješenja Šašića Kirinskoga.

Tablica 1. Supostavni prikaz vojnoga nazivlja u Šuleka, Kirinskoga i Vukovića

\begin{tabular}{|l|l|l|}
\hline \multicolumn{1}{|c|}{$\begin{array}{c}\text { BogOSLAV ŠULEK } \\
(1870 .-1875 .)\end{array}$} & S. S. KIRINSKI (1874.) & \multicolumn{1}{c|}{ IVAN VUKOVIĆ (1875.) } \\
\hline čin & čin & šarža \\
\hline disciplina i red & zapt i red & zapt i red \\
\hline dundarina & brigada & brigada \\
\hline dundarnik & brigadir & brigadir \\
\hline gjeneral & general & general \\
\hline halabuka & vika & vika \\
\hline kazan & kazna & kazna \\
\hline krnjenje & sakaćenje & sakaćenje \\
\hline nagovorenik & zavedenik & zavedenik \\
\hline oblaznica & okolka & okolka \\
\hline odbjeg & bjegunac & bjegunac \\
\hline odbjegstvo & bjeg & bjeg \\
\hline opovied & prijava & prijava \\
\hline popečiteljstvo & ministarstvo & ministarstvo \\
\hline predstraža & prednja straža & prednja straža \\
\hline predvodnica & predhodnica & predhodnica \\
\hline- & prikupni znak & znak za smještanje \\
\hline
\end{tabular}




\begin{tabular}{|l|l|l|}
\hline priprega & podvozni konji & podvozni konji \\
\hline pukovina & pukovnija & pukovnija \\
\hline satnina & satnija & satnija \\
\hline satninski & satnijski & satnijski \\
\hline smotra & pregledba & pregledba \\
\hline snovanje kovarstva na bijeg & kovarstvo bjega & namišljaj bjegunstva \\
\hline snubljenje u vojsku & sakupljanje vojske & sakupljanje vojske \\
\hline spremište & skladište & skladište \\
\hline starješina & stariji & predpostavljeni \\
\hline strielivo & streljivo, strjelivo & streljivo \\
\hline sukrivac zločina & ortak & ortak \\
\hline stapski častnik & pračastnik & pračastnik \\
\hline tisućina & tisućnija, batalijun & bataljun \\
\hline topovje & topovlje & topovlje \\
\hline tvarina $($ Material) & stvari & stvari \\
\hline utvrdjeno mjesto & tvrdjava & tvrdjava \\
\hline vojna četa & zalaznica & četa na polju \\
\hline vojnara & vojarna, vojačnica & vojarna \\
\hline zakletva & prisega & prisega \\
\hline zapovjedka & zapovied \\
\hline zaštitnica & & \\
\hline
\end{tabular}

Rezultati na uzorku od 38 nasumično odabranih naziva zorno ukazuju u prvome redu na prilična terminološka podudaranja između Vukovića i Šašića Kirinskoga. S druge strane, u Šuleka su evidentna drukčija rješenja, kojima je on nastojao biti dosljedan u svim priručnicima dostupnim ovomu istraživanju. ${ }^{11}$ Nadalje, iščitavanjem tekstova uočljiva su preklapanja u nizu rečeničnih, sintagmatskih i kolokacijskih sklopova Vukovićeva i Šašićeva Službovnika (Tablica 2).

${ }_{11}$ To se prije svega odnosi na svih 15 svezaka Naredbenika, Ustrojne ustanove i Domobranski žepnik. 
Tablica 2. Prikaz podudaranja prijevoda Službovnika u Kirinskoga i Vukovića

\begin{tabular}{|c|c|}
\hline S. S. Kirinski Službovnik (1874.) & an Vuković Službovnik (1875.) \\
\hline $\begin{array}{l}\text { Puške, obkopno oružje (Pionir- } \\
\text { Werkzeuge), bubnjevi i trube (Hörner) } \\
\text { povješaju se na hodnicima o klinčenjake } \\
\text { tomu odredjene, a gdje ovako biti } \\
\text { nemože, u sobama uz postelje dotičnih } \\
\text { ljudi. Na odjećnim policama a vrh } \\
\text { sredine svake postelje visi telećak i } \\
\text { čutura, kraj njih s jedne strane ker, a }\end{array}$ & $\begin{array}{l}\text { svake postelje visi telećak i čutura, } \\
\text { kraj njih s jedne strane nabojnjača } \\
\text { (Patrontasche), a izpreko njega pojas s } \\
\text { bodom (Bajonnet) ili sabljom. }\end{array}$ \\
\hline
\end{tabular}

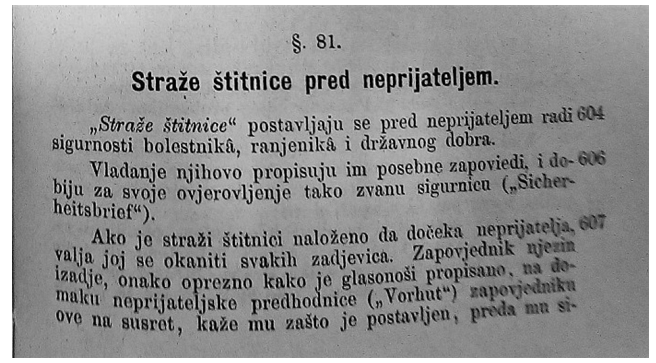

Slika 4. Izvadak iz Službovnika, prijevod S. S. Kirinski, str. 101 (1874.) [C NSK sign. 156.329]

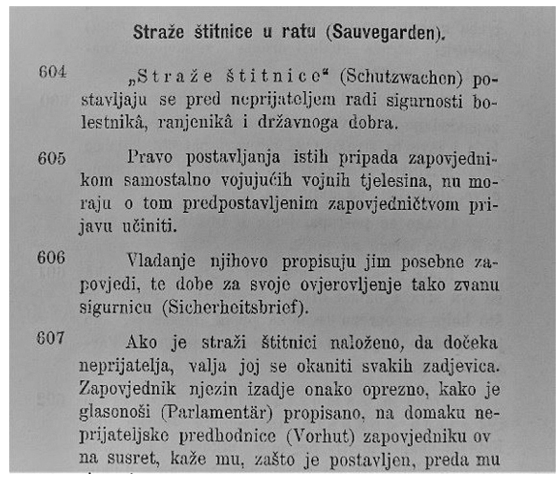

Slika 5. Službovnik za

domobranstvo, prijevod Ivan

Vuković, str. 270 (1875.)

[C zbirka autora]

Sve navedeno govori u prilog hipotezi da se Ivan Vuković pri prijevodu umnogome oslanjao na godinu dana ranije objavljen Izvadak iz Službovnika Šašića Kirinskoga. U kontekstu onodobnih raznorodnih filoloških strujanja usmjerenih k usustavljivanju norma standardnoga jezika, slovopis, pravopis i jezik teksta Službovnika valja smjestiti u okvire zagrebačke filološke škole što podrazumijeva: ${ }^{12}$ pretežito morfonološki pravopis (npr. pješačtvo, častnik, obskrba), pisanje dočetnoga - $h$ u imeničnom genitivu množine (npr. o pritužbah,

\footnotetext{
12 Za slojevito oprimjerenu raščlambu ključnih stremljenja zagrebačke filološke škole, a osobito u odnosu na Šuleka, više v. u Horvat i Mihaljević (2019: 47-50). Primjeri u ovome radu prate sintezu Horvat i Mihaljević.
} 
u domobranskih postajah), čuvanje nesinkretizma padežnih nastavaka množine imenica u DLI (D zapoviedim, L u zapoviedih, I pred zastavami), sloboda u oblikovanju znanstvenoga nazivlja (npr. pračastnik -Stabsoffizier, topovlje Artilleriepark, spravište - Depot, stražište - Wachposten, tjelesina - Körper). U sva tri autora jasan je umjereni puristički pristup oblikovanju nazivlja. Ipak, Šulek je po tome pitanju konzistentniji jer na mjestima ustraje na hrvatskoj ili barem slavenskoj riječi (tisućina umjesto bataljun, sukrivac umjesto ortak, čin umjesto $\check{s}$ arža, popečiteljstvo umjesto ministarstvo).

Druga prosudba koja se redovito perpetuirala u literaturi jest da su se sve knjižice „u Šulekovu prijevodu kasnije pretiskivale, npr. Službovnik za kr. ugarsko domobranstvo. Dio drugi. Drugo izdanje Službovnika od god. 1875, Budimpešta 1888" (Vince 1990: 564). Međutim, valja znati da je pri ugarskome Ministarstvu zemaljske obrane od 1870. nadalje djelovao XX. Odjel za poslove prevođenja s mađarskoga na hrvatski i redigiranja hrvatskoga izdanja službenog lista Ministarstva (Viestnik naredabah). Osim Viestnika Ministarstvo je, prema Horel, u budimpeštanskoj izdavačkoj kući Pallas objavljivalo literaturu namijenjenu domobranstvu i oružništvu (Horel 2015: 149), među njima i sva izdanja Službovnika objavljena do kraja Prvoga svjetskog rata. Premda Vince navodi da su kasnija izdanja Službovnika pretisci, ovdje se na temelju uvida u građu ne podupire takva ocjena. Usporedbom zagrebačkoga prvotiska iz 1875. i drugoga, budimpeštanskoga izdanja Službovnika iz 1887., očito je da je prvo izdanje doživjelo redigiranje i leksičko-gramatičke izmjene najvjerojatnije unutar XX. Odjela ugarskoga Ministarstva zemaljske obrane. K tome, Pallasovo reizdanje Službovnika (1901.) nosi na naslovnici uokvirenu napomenu patisak, obavljen uvaženjem izpravaka, koji su usliedili do mjeseca listopada god. 1900. što dodatno potvrđuje takvu tezu. Navedimo samo nekoliko primjera ,izpravaka” učinjenih od 1875. do 1887. (Tablica 3). ${ }^{13}$

\footnotetext{
13 Intrigira podatak koji donosi Martinčić (2020: 134), pozivajući se na Miroslava Krležu, da je npr. Vježbovnik za kraljevsko ugarsko-hrvatsko domobransko pješačtvo, također ovim radom dokazano nastao iz pera podmaršala Ivana Vukovića, dotjerivao ,akademik Tomo Maretić, koji se kasnije svojim djelima obračunao s jezičnom koncepcijom hrvatskoga standardnog jezika zagrebačke filološke škole.
} 
Tablica 3. Prikaz promjene nazivlja Službovnika iz 1887. u odnosu na 1875.

\begin{tabular}{|c|c|}
\hline Službovnik (1875.) & Službovnik (1887.) \\
\hline buna (Aufruhr) & nabuna \\
\hline domobranac & domobran \\
\hline dosmrtna tamnica & doživotna tamnica \\
\hline mjesto (stražara) & postavište \\
\hline neobična sila & izvanredna sila \\
\hline patrola & obhodja \\
\hline stražar & stražnik \\
\hline$\check{s}$ šrža & čin \\
\hline ubijstvo & ubojstvo \\
\hline
\end{tabular}

Zaključnom ocjenom možemo reći da se pristup jezičnoj koncepciji hrvatskoga standardnog jezika u hrvatskome domobranstvu u svemu, od početka 1868. do samoga kraja 1918., oslanjao na načela zagrebačke škole.

Progovorimo li o prevladavajućoj procjeni u literaturi da su Šulekovi „tiskopisi” uglavnom nestali (Martinčić 2020: 133), treba naglasiti kako je ovo istraživanje metodološki nastalo uvidom u fizičke primjerke 20 priručnika dokazano pripisivih Šuleku (signature u prilogu), šest priručnika Šašića Kirinskoga te prvotiska Vukovićeva Službovnika (1875.) iz osobne zbirke autora ovoga rada. Biobibliografski se podatci donose u Prilogu 1, a time i provjerljiva prosudba o dostupnosti primarnih izvora.

Na kraju ovoga razdjela progovorimo ponovno o Šuleku. Da je niz autora različitih profila stajao iza nepotpisanih prijevoda vojnih priručnika, govori i podatak da se u istome broju Vienca iz 1875., uz Vukovića i još neke časnike ujedno i prevoditelje, spominje kako je Ustrojne ustanove za opremljenu ugarskoaustrijsku vojsku. Treći diel: Naputak za vojničko opremanje po vodi, ,preveo dr. Šulek iz magjarskoga po nalogu kr. ug. ministarstva za obranu zemlje" (Vienac, br. 40, 2. listopada 1875.). Taj se Šulekov naslov do danas u literaturi nije nigdje spominjao, stoga taj podatak zorno upućuje na zaključak da Šulekov rad na vojnome nazivlju nije stao na popisu prevedenih priručnika iz 1874., nego se nastavio. Dosadašnji podatak od 26 Šulekovih priručnika ovim istraživanjem raste na sveukupno 29. 


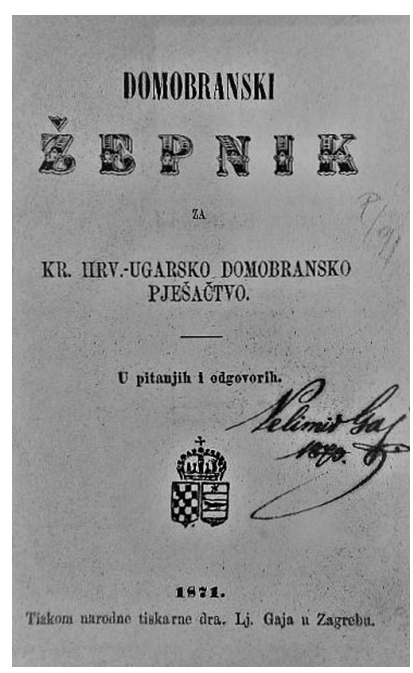

Slika 6. Domobranski žepnik, prijevod Bogoslav Šulek (1871.)

[C NSK 156.512]

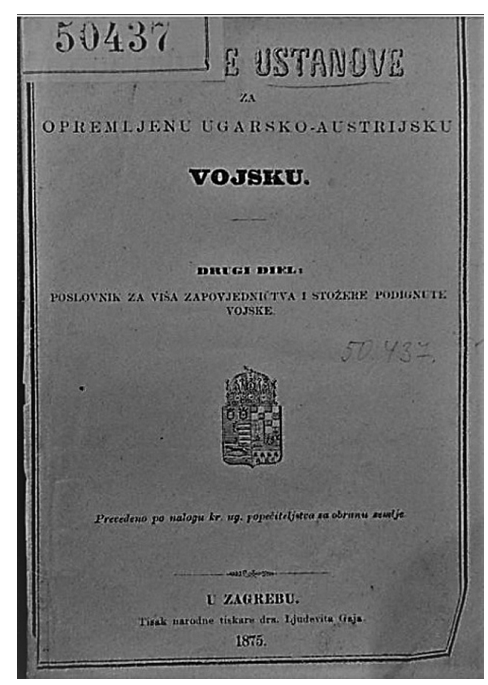

Slika 7. Ustrojne ustanove, prijevod Bogoslav Šulek (1875.)

[C NSK 156.512]

\subsection{Domobranski časnički kadar i daljnji vojnoterminografski prinosi}

Rubrika iz Vienca o novoobjavljenim „vojničkim knjigama” (1875./1876.), uz „nadporučnika i profesora Vukovića” te „dr. Šuleka”, donosi još nekoliko naslova s popratnim kraćim komentarima te podatcima o prevoditeljima. Redom je riječ o časnicima, pripadnicima hrvatskoga domobranstva. Pridodamo li Šulekovim priručnicima i sve ostale evidentirane ovim istraživanjem, dolazimo do impozantnoga broja od 55 vojnoterminografskih ostvarenja objavljenih u Hrvatskoj u razdoblju ključnom za ustrojavanje domobranstva, a samim time i nazivlja (1868. - 1877.). Ti brojevi još osjetnije rastu ubroje li se i kasnije publikacije objavljivane u budimpeštanskome Pallasu.

Integralni se podatci donose u Prilogu 1 , a ovdje će se ugrubo pokušati portretirati njihovi autori:

1. Eugen Rónai-Horváth von Uzsok (30. 12. 1852. - 3. 3. 1915.), tada domobranski kapetan, a pred umirovljenje podmaršal 
2. Juraj Grbačić, cesarsko kraljevski poručnik 48. pješačke pukovnije

3. Marko Tomičić, računarski oficial ${ }^{14}$ kod kraljevskoga domobranstva.

Krajnje je zanimljiv sljedeći komentar uz naslov knjige Juraja Grbačića, kojim se zaključuje ovaj kraći niz vojnoterminografskih zaslužnika:

U ovoj knjizi nalazimo nekoliko izvrstnih posve narodnih tehničkih izraza, koje bi valjalo prihvatiti u mjesto skovanih izraza, koji se sad upotrebljuju, i koji su stvoreni ne opitav prosta vojnika, kako se ovo ili ono krsti. (Vienac, br. 9, 1876.)

\subsection{Domobranski časnici autori vojnojezičnih priručnika}

\subsubsection{Hrvatski vojni jezik - prvi hrvatski vojnojezični priručnik (1887.)}

Nepunih 20 godina po uvođenju hrvatskoga kao službenoga i zapovjednoga jezika u kraljevsko-ugarsko domobranstvo svjetlo dana ugledaoje zanimljiv vojnojezični priručnik na gotovo dvjestotinjak stranica Kroatische Militär=Sprache (Ein Handbuch für den Vorgesetzen im Verkehre mit den Untergebenen). Objavljen je u Beču 1887. godine, a autor mu je onodobni domobranski časnik, natporučnik Alois Vuković von Vedropoljski. ${ }^{15}$ Priručnik je višedimenzijski, tako da ga čine pregled gramatike hrvatskoga jezika, vojnokonverzacijski priručnik i njemačko-hrvatski pojmovnik (rječnik) koji donosi mješoviti općejezični i vojnojezični leksik. Polazni je jezik priručnika njemački, a rječnik sadržava oko 2200 polaznih njemačkih natuknica. Jezično se naslanja na nastojanja i rješenja Bogoslava Šuleka i zagrebačke filološke škole - od umjerenoga purizma (voditba, skupište, provedbena ustanova) do čuvanja nesinkretizma padežnih nastavaka množine imenica u DLI (D zapoviedim, L zapoviedih, I zapoviedmi) i morfonološkoga pravopisa (pješačtvo, častnik, nepriatelj).

\footnotetext{
14 Jedna među kategorijama domobranskih činovnika. Usp. Službovnik iz 1887., str. 402.

15 Na naslovnici Vuković je potpisan kao $k$. $k$. Oberlieutenant im Peterwardeiner Infanterie=Regimente Freiherr von Philippović Nr. 70, Lehrer an der Infanterie=Cadetenschule zu Karlstadt. Alois Vuković rođen je 1852. u Primišlju kraj Slunja 1857. godine, tako da je kao tridesetogodišnjak objavio ovo djelo. Godine 1878. sudjelovao je u aneksiji Bosne i Hercegovine te je bio višegodišnji predavač u kadetskoj školi u Karloveu (Svoboda 1894: 694-95).
} 


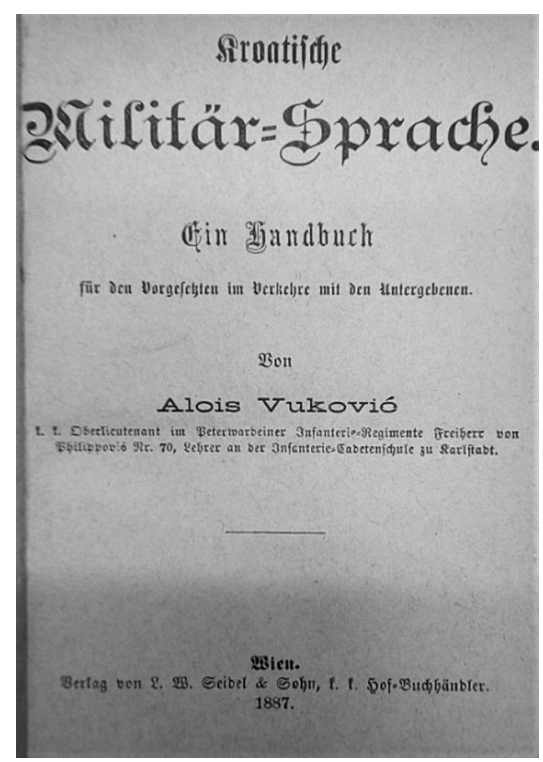

Slika 8. Kroatische Militär=Sprache, Alois Vuković, (1887.) [C NSK, sign. 156.210]

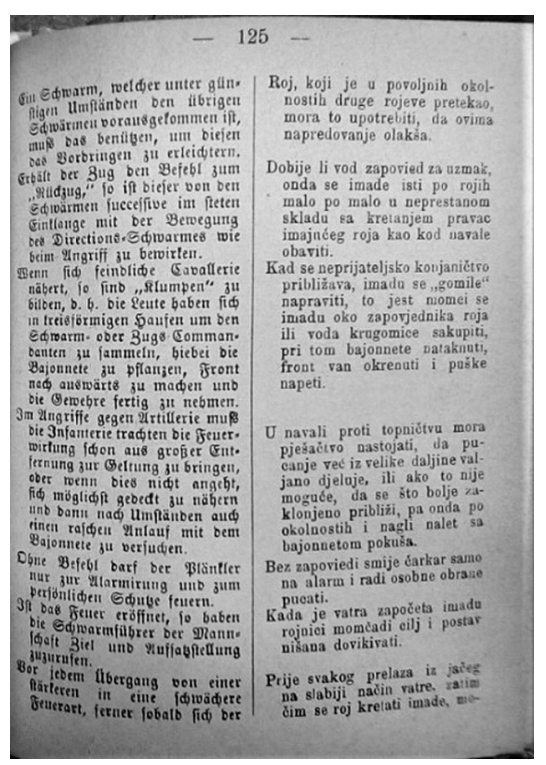

Slika 9. Kroatische Militär=Sprache, Alois Vuković, str. 125 (1887.)

[C NSK, sign. 156.210]

Osim samoga rječničkoga dijela, bogatstvu leksičkoga fonda pridonosi i vojnokonverzacijski priručnik, koji u jednakoj mjeri može poslužiti kao nazivoslovni bazen za daljnja istraživanja. Zanimljivo je kako na kraju gramatičkoga dijela Vuković, osim vojnih priručnika, za „daljnja istraživanja” preporučuje i dva jezična naslova: dvojezičnik Ivana Filipovića Kroatisch (serbisch)-deutsches Konversationsbuch i gramatiku Josipa Galla Kurzgefasste Practische Grammatik der kroatischen Sprache. ${ }^{16}$

Nedvojbeno, posrijedi je vrijedan dvojezični jezično-terminološki priručnik koji svjedoči o važnosti statusa i prepoznatljivosti hrvatskoga jezika u austro-ugarskoj vojsci. Štoviše, po svoj prilici, riječ je o prvome hrvatskom vojnojezičnom priručniku. Priručnik se čuva u Nacionalnoj i sveučilišnoj knjižnici u Zagrebu pod signaturom 156.210 .

\footnotetext{
16 Kurzgefasste Practische Grammatik Der Kroatischen Sprache: Mit Vielen Gesprächen, Redensarten U.; Oder, Vademecum Für Reisende in Kroatien, Slavonien, Bosnien, Hercegovina und Serbien, Agram (1882.).
} 


\subsubsection{Njemačko-hrvatski vojni rječnik (1893.)}

Premda naslovljen kao rječnik (njem. Wörterbuch), Deutsch-Kroatisches Militär-Wörterbuch tiskan u Beču 1893. službeni je njemačko-hrvatski vojnojezični priručnik sličan onomu Aloisa Vukovića objavljenom šest godina ranije. ${ }^{17}$ Dostupni podatci o autoru oskudni su, no prema naslovnici riječ je o časniku topničke regimente, satniku Isaku Ljuštini. Djelo karakterizira koncepcija tipična za onodobne jezične priručnike objavljivane za potrebe mnogojezične Monarhije - svojevrsni triptih sastavljen od gramatičkoga, rječničkoga i konverzacijskoga dijela. Kad govorimo o standardnojezičnoj orijentaciji, Ljuština se pretežito oslanja na zasade zagrebačke filološke škole - pravopis (obkopnik, pješačtvo, strieljivo), umjereni purizam i hrvatska tvorba (glavnik, ${ }^{18}$ čizmomaz, prohod, plivarnica, uzglavnica, ${ }^{19}$ nado $^{20}$ ), nastavak - ah u genitivu množine imenica (držite kraj uzdah). Ipak, odustaje od čuvanja nesinkretizma padežnih nastavaka množine imenica u DLI.

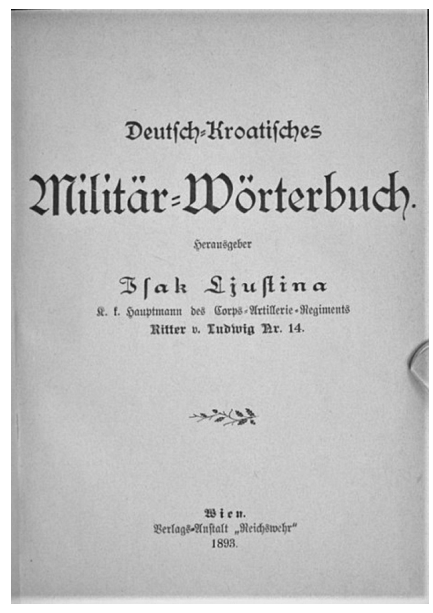

Slika 10. Deutsch-Kroatisches Militär-Wörterbuch, Isak Ljuština (1893.) [C Österreichische Nationalbibliothek, sign. 77906-A]

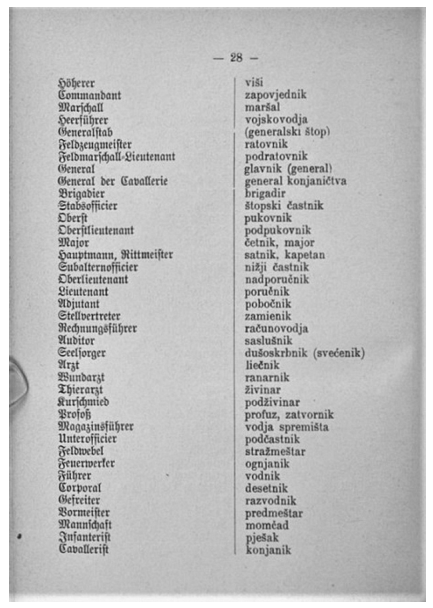

Slika 11. Deutsch-Kroatisches Militär-Wörterbuch, Isak Ljuština (1893.) str. 28 [C Österreichische Nationalbibliothek, sign. 77906-A]

\footnotetext{
7 Za vojnojezični priručnik Aloisa Vukovića usp. ovdje 4.3.1.

18 Bogoslav Šulek predlagao je naziv glavnik umjesto general.

19 Uzglavnica umjesto turcizma jastuk.

20 Nado umjesto turcizma čelik.
} 
Rječnička građa nije isključivo vezana uz vojništvo, nego nudi i vojnicima nužan općerječnički leksik. Sâm rječnički dio sadržava okvirno 1200 njemačkih polaznih natuknica i nešto više hrvatskih istovrijednica. Izluče li se nazivi iz konverzacijskoga priručnika, leksički fond još više raste, tako da priručnik služi kao ozbiljna podloga temeljnoga hrvatskog vojnog nazivlja s kraja 19. stoljeća. Rječnik se čuva u Austrijskoj nacionalnoj biblioteci u Beču pod signaturom 77906-A.

Zaključimo da, premda neveliki opsegom, Militär-Wörterbuch Isaka Ljuštine zajedno s vojnojezičnim priručnikom Aloisa Vukovića zauzima važno mjesto u postanku hrvatskoga vojnog nazivlja.

\section{Zaključak}

Većina dosadašnjih znanstvenoistraživačkih spoznaja o početcima izgradnje hrvatskoga vojnog nazivlja počivala je na temeljnoj premisi o Bogoslavu Šuleku kao njegovu utemeljitelju. Proučavanja su se stoga redovito usredotočivala na njegova djela ili na djela koja bi se nesumnjivo morala pripisati Šuleku. Nerijetko bi sekundarni izvori služili kao polazna točka. Šulekov se leksikografski autoritet i vojnoterminografski opus pokazao do te mjere epohalnim da znanstvena propitivanja nisu išla onkraj već neprijepornih činjenica desetljećima prikazivanih u literaturi.

Ipak, ovim se istraživanjem nastojala rasvijetliti svojevrsna terra incognita oblikovanja i usustavljivanja hrvatskoga vojnog nazivlja iz druge polovice 19. stoljeća. Rezultati rada višeslojni su te upućuju na novu konfiguraciju donedavnih spoznaja o samim početcima oslužbenjivanja vojnoleksičkoga fonda i protagonistima njegova stvaranja. Naime, istraživanjem su potvrđene sljedeće hipoteze rada: 1. Bogoslav Šulek nije bio jedini koji je preveo i objavio službene „vojničke knjige” za domobranstvo, 2. Šulekovu su se peru pogrešno pripisivali prijevodi pojedinih važnih priručnika, 3. Šulek je preveo još nekoliko vojnih knjižica u odnosu na broj koji se do danas spominjao u literaturi i 4. glavnina Šulekova vojnoterminografskoga opusa nije nestala.

Budući da je kao polazište za podrobnije istraživanje poslužio rad kojim je već ustanovljeno postojanje predšulekovske vojne literature službeno namijenjene 
domobranstvu, rezultati ovoga rada dodatno upotpunjuju vojnoterminografski mozaik. U prvome redu uspostavljeno je da je niz visokih domobranskih časnika u jeku ustrojavanja vojnoleksičkoga fonda (1868. - 1876.) preveo i objavio niz priručnika. Štoviše, dokazuje se da je nekima od njih bilo pogrešno pripisivano Šulekovo autorstvo. Časničku elitu predvodio je podmaršal i profesor na budimpeštanskome Ludoviceumu Ivan Vuković, koji je preveo glasoviti Službovnik i Vježbovnik, čiji korpusi objedinjeno čine 940 stranica teksta. Upravo se za taj Službovnik u literaturi držalo da iza njega stoji Šulek. Istraživanjem su utvrđena i pionirska ostvarenja vojnojezične leksikografije - Njemačko-hrvatski vojni rječnik satnika Isaka Ljuštine (1893.) te Hrvatski vojni jezik natporučnika Aloisa Vukovića (1887.) - koja se, po svoj prilici, prvi put iznose na vidjelo stručnoj i široj javnosti.

Usporedba Šulekova nazivlja s nazivljem nešulekove literature upućuje na osjetnija nazivotvorna podudaranja među naslovima iza kojih su stajali časnici negoli s onim Šulekovim. Međutim, u svim je priručnicima jasna opredijeljenost jezičnoj koncepciji zagrebačke filološke škole, a kojoj je domobranstvo bilo vjerno u svim svojim izdanjima sve do 1918. Jednako tako, dokumentirano je da je glavnina Šulekovih naslova preživjela, a čuvaju se uglavnom u nacionalnim fondovima, dok se prvotisak toliko citiranoga Vukovićeva Službovnika iz 1875. nalazi u zbirci autora ovoga rada. Konačno, utvrđen je i broj Šulekovih priručnika, koji se ovim radom zaustavlja na 29. Popis evidentiranih vojnostručnih i vojnojezičnih priručnika donosi se u Prilogu 1.

Nesumnjivo, vrh vojnoterminološkoga panteona pripada nazivotvornomu virtuozu Bogoslavu Šuleku, koji svojim opusom i dalje nadmašuje ovdje predstavljena ostvarenja domobranskih časnika. Ipak, afirmirajući ih ovim radom i oni postaju zaslužnicima sustvaranja „domobranskoga” nazivlja. Stoga ih nabrajamo redom: podmaršal Ivan Vuković, podmaršal Eugen Rónai-Horváth von Uzsok, potpukovnik Stjepan pl. Šašić Kirinski, satnik Isak Ljuština, natporučnik Alois Vuković, poručnik Juraj Grbačić, računarski oficijal Marko Tomičić. Drugim riječima, riječ je o intelektualnoj domobranskoj eliti posvećenoj hrvatskoj vojnoj riječi, koja je sve dosad uglavnom promicala znanstvenoistraživačkomu povećalu. 


\section{PRILOG}

Prilog 1. Popis vojnostručne literature objavljene u Hrvatskoj od ustroja domobranstva 1868. do $1877 .{ }^{21}$

\begin{tabular}{|c|c|c|c|c|}
\hline GODINA & NASLOV & MJESTO I TISAK & $\begin{array}{l}\text { PREVODITELJ/ } \\
\text { AUTOR }\end{array}$ & POHRANA \\
\hline $\begin{array}{l}\text { sine } \\
\text { anno }\end{array}$ & $\begin{array}{l}\text { Izvadak iz Obučevnika } \\
\text { na porabu hrvatskomu } \\
\text { domobranstvu }\end{array}$ & $\begin{array}{l}\text { Zagreb, narodna } \\
\text { tiskarnica dra. } \\
\text { Ljudevita Gaja }\end{array}$ & sine nomine & $\begin{array}{l}\text { NSK (sign. } \\
301.638)\end{array}$ \\
\hline 1868. & $\begin{array}{l}\text { Izvadak iz Službovnika za } \\
\text { ces. kralj. pješačtvo }\end{array}$ & $\begin{array}{l}\text { Zadar, tiskom } \\
\text { narodnoga Lista }\end{array}$ & sine nomine & $\begin{array}{l}\text { NSK (sign. } \\
158.840)\end{array}$ \\
\hline 1868. & $\begin{array}{l}\text { Izvadak iz Službovnika } \\
\text { ces. kralj. pješačtva }\end{array}$ & $\begin{array}{l}\text { Zagreb, Tiskom } \\
\text { A. Jakića }\end{array}$ & $\begin{array}{l}\text { Stjepan } \\
\text { pl. Šašić- } \\
\text { Kirinski }\end{array}$ & $\begin{array}{l}\text { NSK (sign. } \\
156.578)\end{array}$ \\
\hline 1868. & $\begin{array}{l}\text { Izvadak iz Službovnika } \\
\text { ces. kralj. pješačtva, } 2 . \\
\text { izd. }\end{array}$ & $\begin{array}{l}\text { Zagreb, Tiskom } \\
\text { A. Jakića }\end{array}$ & $\begin{array}{l}\text { Stjepan } \\
\text { pl. Šašić- } \\
\text { Kirinski }\end{array}$ & $\begin{array}{l}\text { NSK (sign. } \\
156.578)\end{array}$ \\
\hline 1868. & $\begin{array}{l}\text { Pouka o ustrojstvu } \\
\text { čistitbi, pregledbi, } \\
\text { čuvanju i postupanju } \\
\text { puške: po Waenzlovom } \\
\text { sustavu prepravljene i o } \\
\text { njezinu streljivu }\end{array}$ & $\begin{array}{l}\text { Zagreb, } \\
\text { brzotiskom } \\
\text { Antuna Jakića }\end{array}$ & $\begin{array}{l}\text { Stjepan } \\
\text { pl. Šašić- } \\
\text { Kirinski }\end{array}$ & $\begin{array}{l}\text { NSK (sign. } \\
159.459)\end{array}$ \\
\hline 1869. & $\begin{array}{l}\text { Naputak za izpitivanje } \\
\text { i preuzimanje pješačke } \\
\text { puške Werndlova sustava, } \\
\text { a za puškare kako da š } \\
\text { njomn postupaju }\end{array}$ & Zagreb & sine nomine & NSK (I.1.418) \\
\hline 1870. & $\begin{array}{l}\text { Izvadak iz c. kr. } \\
\text { obučevnika na porabu kr. } \\
\text { ug.-hrvatskom konjaničtvu }\end{array}$ & Zagreb & sine nomine & NSK \\
\hline $\begin{array}{l}1870 .- \\
1873 .\end{array}$ & $\begin{array}{l}\text { Naredbenik za kraljevsko } \\
\text { hrvatsko-ugarsko } \\
\text { domobranstvo, sv. } 1 .-15 .\end{array}$ & $\begin{array}{l}\text { Zagreb, tiskom } \\
\text { narodne tiskare } \\
\text { dra. Ljudevita } \\
\text { Gaja }\end{array}$ & $\begin{array}{l}\text { Bogoslav } \\
\text { Šulek }\end{array}$ & $\begin{array}{l}\text { NSK (sign. } \\
153.663)\end{array}$ \\
\hline
\end{tabular}

${ }_{21}$ Razdoblje nakon 1868. donosi procvat vojnostručne literature na hrvatskome jeziku, a time i eksponencijalni rast terminološkoga fonda. Premda ne teži biti konačnim popisom, ovo je prvi pokušaj što sveobuhvatnijega prikaza vojnostručne literature objavljivane na ozemlju Hrvatske nakon ustroja hrvatskoga kraljevskog domobranstva koju su, osim Šuleka, prevodili redom sve hrvatski domobranski časnici. Ovdje se ne navodi vojna literatura koju pred kraj 1870-ih nastavlja na hrvatskome jeziku službeno izdavati Ministarstvo za zemaljsku obranu u Budimpešti (izdavač Pallas), kao što je u radu pojašnjeno. 


\begin{tabular}{|c|c|c|c|c|}
\hline 1871. & $\begin{array}{l}\text { Domobranski žepnik } \\
\text { za kr. hrv.-ugarsko } \\
\text { domobransko pješačtvo. } \\
\text { U pitanjah i odgovorih. }\end{array}$ & $\begin{array}{l}\text { Zagreb, tiskom } \\
\text { narodne tiskarne } \\
\text { dra. Ljudevita } \\
\text { Gaja }\end{array}$ & $\begin{array}{l}\text { Bogoslav } \\
\text { Šulek }\end{array}$ & $\begin{array}{l}\text { NSK sign. } \\
156.512\end{array}$ \\
\hline 1871. & $\begin{array}{l}\text { Obučevnik ces. kralj. } \\
\text { pješačtva }{ }^{22}\end{array}$ & \begin{tabular}{|l} 
Vojni Sisak, \\
brzotiskom I. \\
Vončine \\
\end{tabular} & $\begin{array}{l}\text { Stjepan } \\
\text { pl. Šašić- } \\
\text { Kirinski }\end{array}$ & $\begin{array}{l}\text { HAZU (sign. } \\
82.917-\mathrm{Rn})\end{array}$ \\
\hline 1871. & $\begin{array}{l}\text { Nova ratna služba c. } k r \text {. } \\
\text { vojske za podčastnike } i \\
\text { momčadske učione }\end{array}$ & $\begin{array}{l}\text { Vojni Sisak, } \\
\text { brzotiskom I. } \\
\text { Vončine } \\
\end{array}$ & $\begin{array}{l}\text { Stjepan } \\
\text { pl. Šašić- } \\
\text { Kirinski }\end{array}$ & $\begin{array}{l}\text { HAZU (sign. } \\
\text { 86.096-Rn) }\end{array}$ \\
\hline 1871. & $\begin{array}{l}\text { Pouka o uredbi, } \\
\text { čuvanju, pregledavanju } \\
\text { i postupanju puškom po } \\
\text { Waenzlovom sustavu } \\
\text { preradjenom i o njezinu } \\
\text { strjelivu }\end{array}$ & $\begin{array}{l}\text { Vojni Sisak, } \\
\text { brzotiskom I. } \\
\text { Vončine }\end{array}$ & $\begin{array}{l}\text { Stjepan } \\
\text { pl. Šašić- } \\
\text { Kirinski }\end{array}$ & $?$ \\
\hline 1872. & $\begin{array}{l}\text { Uputa u zdravstvenu } \\
\text { službu za kr. ug. } \\
\text { domobranstvo }\end{array}$ & Zagreb? & $\begin{array}{l}\text { Bogoslav } \\
\text { Šulek }\end{array}$ & $?$ \\
\hline 1872. & $\begin{array}{l}\text { Pouka o pucanju za kr. ug. } \\
\text { domobranstvo }\end{array}$ & Zagreb? & $\begin{array}{l}\text { Bogoslav } \\
\text { Šulek }\end{array}$ & $?$ \\
\hline 1872. & $\begin{array}{l}\text { Naputak za domobranske } \\
\text { nosiče ranjenikah }{ }^{23} i \\
\text { zdravnika }\end{array}$ & Zagreb? & $\begin{array}{l}\text { Bogoslav } \\
\text { Šlek }\end{array}$ & $?$ \\
\hline 1872. & $\begin{array}{l}\text { Obučevnik za kr. hrv. ug. } \\
\text { domobranske tarničare }\end{array}$ & Zagreb? & $\begin{array}{l}\text { Bogoslav } \\
\text { Šulek } \\
\end{array}$ & $?$ \\
\hline 1873. & $\begin{array}{l}\text { Obučevnik za kr. ugarsko } \\
\text { domobransko konjaničtvo } \\
\text { (Službeno izdanje) }\end{array}$ & $\begin{array}{l}\text { Zagreb, tiskom } \\
\text { narodne tiskare } \\
\text { dra. Ljudevita } \\
\text { Gaja }\end{array}$ & $\begin{array}{l}\text { Bogoslav } \\
\text { Šulek }\end{array}$ & $\begin{array}{l}\text { NSK (sig. } \\
191.767)\end{array}$ \\
\hline 1873. & $\begin{array}{l}\text { Ustrojne ustanove za } \\
\text { opremljenu ugarsko- } \\
\text { austrijsku vojsku. Prvi } \\
\text { diel: Ustrojben propisnik. } \\
\text { Prevedeno po nalogu kr. } \\
\text { ugarskoga popečiteljstva } \\
\text { za obranu zemlje. }\end{array}$ & $\begin{array}{l}\text { Zagreb, tiskom } \\
\text { narodne tiskare } \\
\text { dra. Ljudevita } \\
\text { Gaja }\end{array}$ & $\begin{array}{l}\text { Bogoslav } \\
\text { Šulek }\end{array}$ & $\begin{array}{l}\text { NSK (sign. } \\
50.437)\end{array}$ \\
\hline
\end{tabular}

22 U Viencu br. 43 (1871.) napomena: Ova je knjiga već s toga znamenita, što ju je naše domobranstvo odobrilo i usvojilo. Doći će ona dakle dobro svim našim sadašnjim i budućim domobrancem.

${ }^{23}$ Martinčić (2020: 131) sjajno upućuje na lapsus calami koji se desetljećima prepisivao u literaturi, gdje je umjesto ranjenikah stajalo zamjenikah, iz čega je proizišao „,nerazumljiv zbunjujući naslov” Naputak za domobranske nosiče zamjenikah i zdravnikah. 


\begin{tabular}{|c|c|c|c|c|}
\hline 1873. & $\begin{array}{l}\text { Uputa u pravljenje } \\
\text { vježbovnih nabojakah za } \\
\text { kr. ug. domobranstvo }\end{array}$ & Zagreb? & $\begin{array}{l}\text { Bogoslav } \\
\text { Šlek }\end{array}$ & $?$ \\
\hline 1873. & $\begin{array}{l}\text { Vježbovnik za kr. ugarsko } \\
\text { domobransko konjaništvo }\end{array}$ & Zagreb & $\begin{array}{l}\text { Bogoslav } \\
\text { Šulek }\end{array}$ & $\begin{array}{l}\text { NSK (sign. } \\
153.907)\end{array}$ \\
\hline 1874. & $\begin{array}{l}\text { Obučevnik za kraljevsko- } \\
\text { ugarske domobranske } \\
\text { sipačarske odjele. } \\
\text { (Službeno izdanje) }\end{array}$ & $\begin{array}{l}\text { Zagreb, tiskom } \\
\text { narodne tiskare } \\
\text { dra. Ljudevita } \\
\text { Gaja }\end{array}$ & $\begin{array}{l}\text { Bogoslav } \\
\text { Šulek }\end{array}$ & $\begin{array}{l}\text { NSK (sign. } \\
151.836)\end{array}$ \\
\hline 1874. & $\begin{array}{l}\text { Vježbovnik za kraljevsko- } \\
\text { ugarske domobranske } \\
\text { sipačarske odjele }\end{array}$ & Zagreb? & $\begin{array}{l}\text { Bogoslav } \\
\text { Šulek }\end{array}$ & $?$ \\
\hline 1874. & $\begin{array}{l}\text { Izvadak iz Službovnika } \\
\text { ces. kr. vojske namienjen } \\
\text { službenicima nižim od } \\
\text { vôdnika }{ }^{24}\end{array}$ & $\begin{array}{l}\text { Zagreb, tiskom } \\
\text { Dioničke tiskare }\end{array}$ & $\begin{array}{l}\text { Stjepan } \\
\text { pl. Šašić- } \\
\text { Kirinski }\end{array}$ & $\begin{array}{l}\text { NSK (sign. } \\
156.329)\end{array}$ \\
\hline 1874. & $\begin{array}{l}\text { Pouka o pucanju za } \\
\text { sipačarske odjele kr. ug. } \\
\text { domobrani }\end{array}$ & $\begin{array}{l}\text { Zagreb, tiskom } \\
\text { narodne tiskare } \\
\text { dra. Ljudevita } \\
\text { Gaja }\end{array}$ & $\begin{array}{l}\text { Bogoslav } \\
\text { Šulek }\end{array}$ & $\begin{array}{l}\text { NSK (sign. } \\
158.767 \text { ) }\end{array}$ \\
\hline 1874. & $\begin{array}{l}\text { Pristojbenik za kr. hrv.- } \\
\text { ugar. domobranstvo }\end{array}$ & Zagreb & $\begin{array}{l}\text { Marko } \\
\text { Tomičićć }^{25}\end{array}$ & $?$ \\
\hline 1874. & $\begin{array}{l}\text { Naputak za postupanje } \\
\text { u poslovih poštenja za } \\
\text { kr. ug. domobranstvo } \\
\text { (Službeno izdanje) }\end{array}$ & Zagreb & sine nomine & NSK \\
\hline 1875. & $\begin{array}{l}\text { Ustrojne ustanove za } \\
\text { opremljenu ugarsko- } \\
\text { austrijsku vojsku. Drugi } \\
\text { diel: Poslovnik za viša } \\
\text { zapovjedničtva i stožere } \\
\text { podignute vojske. } \\
\text { Prevedeno po nalogu kr. } \\
\text { ugarskoga popečiteljstva } \\
\text { za obranu zemlje. }\end{array}$ & $\begin{array}{l}\text { Zagreb, tiskom } \\
\text { narodne tiskare } \\
\text { dra. Ljudevita } \\
\text { Gaja }\end{array}$ & $\begin{array}{l}\text { Bogoslav } \\
\text { Šulek }\end{array}$ & $\begin{array}{l}\text { NSK (sign. } \\
50.437)\end{array}$ \\
\hline
\end{tabular}

\footnotetext{
${ }^{24}$ U Viencu br. 32 (1874.) napomena uz naslov: Vrlo praktična knjižica za naše vojnike. U 15 odsieka nacrtao je pisac lakim, razumljivim jezikom cielo službovanje $i$ vojničke propise.

${ }_{25}$ Marko Tomičić, računarski oficijal kod. kr. domobranstva.
} 


\begin{tabular}{|c|c|c|c|c|}
\hline 1875. & $\begin{array}{l}\text { Dodatak k drugomu } \\
\text { dielu ustrojnih ustanova } \\
\text { odnosećih se na } \\
\text { opremljenu austrijsku } \\
\text { vojsku }\end{array}$ & $\begin{array}{l}\text { Zagreb, L. } \\
\text { Hartmana. }\end{array}$ & $\begin{array}{l}\text { Eugen } \\
\text { Rónai- } \\
\text { Horváth von } \\
\text { Uzsok }\end{array}$ & $?$ \\
\hline 1875. & $\begin{array}{l}\text { Ustrojne ustanove za } \\
\text { opremljenu ugarsko- } \\
\text { austrijsku vojsku. Treći } \\
\text { diel: Naputak za vojničko } \\
\text { opremanje po vodi. } \\
\text { Prevedeno po nalogu kr. } \\
\text { ugarskoga popečiteljstva } \\
\text { za obranu zemlje. }\end{array}$ & $\begin{array}{l}\text { Zagreb, L. } \\
\text { Hartmana. }\end{array}$ & $\begin{array}{l}\text { Bogoslav } \\
\text { Šulek }\end{array}$ & $?$ \\
\hline 1875. & $\begin{array}{l}\text { Ustrojne ustanove za } \\
\text { opremljenu ugarsko- } \\
\text { austrijsku vojsku. Treći } \\
\text { diel: Naputak za vojničko } \\
\text { opremanje željeznicom. } \\
\text { str. } 243\end{array}$ & $\begin{array}{l}\text { Zagreb, L. } \\
\text { Hartmana. }\end{array}$ & $\begin{array}{l}\text { Eugen } \\
\text { Rónai- } \\
\text { Horváth von } \\
\text { Uzsok }\end{array}$ & $?$ \\
\hline 1875. & $\begin{array}{l}\text { Vježbenik (Vježbovnik?) } \\
\text { za kralj. hrvatsko-ugarsko } \\
\text { domobransko pješačtvo. I. } \\
\text { dio, strana } 255 .\end{array}$ & $\begin{array}{l}\text { Zagreb, L. } \\
\text { Hartmana. }\end{array}$ & $\begin{array}{l}\text { Ivan } \\
\text { Vuković }\end{array}$ & $?$ \\
\hline 1875. & $\begin{array}{l}\text { Vježbenik (Vježbovnik?) } \\
\text { za kralj. hrvatsko-ugarsko } \\
\text { domobransko pješačtvo. } \\
\text { II. dio strana } 86 \mathrm{~s} 9 \text { tablica }\end{array}$ & $\begin{array}{l}\text { Zagreb, L. } \\
\text { Hartmana. }\end{array}$ & $\begin{array}{l}\text { Ivan } \\
\text { Vuković }\end{array}$ & $?$ \\
\hline 1875. & $\begin{array}{l}\text { Službovnik za kr. } \\
\text { hrvatsko-ugarsko } \\
\text { domobranstvo. I. dio, str. } \\
376\end{array}$ & $\begin{array}{l}\text { Zagreb, L. } \\
\text { Hartmana. }\end{array}$ & \begin{tabular}{|l|} 
Ivan \\
Vuković
\end{tabular} & zbirka Vrgoč \\
\hline 1875. & $\begin{array}{l}\text { Službovnik za kr. } \\
\text { hrvatsko-ugarsko } \\
\text { domobranstvo. II. dio, str. } \\
224 \text { s } 9 \text { tablica }\end{array}$ & $\begin{array}{l}\text { Zagreb, L. } \\
\text { Hartmana. }\end{array}$ & $\begin{array}{l}\text { Ivan } \\
\text { Vuković }\end{array}$ & $\begin{array}{l}\text { NSK, } \\
\text { dostupna } \\
\text { kasnija } \\
\text { izdanja }\end{array}$ \\
\hline 1875. & $\begin{array}{l}\text { Naputak za sastavljanje, } \\
\text { držanje u dobru stanju, } \\
\text { izpitivanje, rukovanje } \\
\text { i spravljanje pješačke } \\
\text { puške Werndlova sustava i } \\
\text { njenog streljiva }\end{array}$ & $\begin{array}{l}\text { Zagreb, L. } \\
\text { Hartmana. }\end{array}$ & $\begin{array}{l}\text { Eugen } \\
\text { Rónai- } \\
\text { Horváth von } \\
\text { Uzsok }\end{array}$ & $?$ \\
\hline
\end{tabular}




\begin{tabular}{|c|c|c|c|c|}
\hline 1875. & $\begin{array}{l}\text { Pouka o sastavu i držanju } \\
\text { u redu, rukovanju, } \\
\text { pregledanju i pohrambi } \\
\text { Montigny-evske sipače } \\
\text { i strieljivnih kolah, } \\
\text { službeno izdanje }\end{array}$ & Zagreb & sine nomine & $\begin{array}{l}\text { NSK } \\
\text { (sign.151.070) }\end{array}$ \\
\hline 1875. & $\begin{array}{l}\text { Pouka o pucanju (osnova) } \\
\text { za kr. ug. Domobransko } \\
\text { pješačtvo }\end{array}$ & Zagreb & sine nomine & $\begin{array}{l}\text { NSK (sign. } \\
71.015)\end{array}$ \\
\hline 1876. & $\begin{array}{l}\text { Puška i streljivo } \\
\text { Werndlova sustava } \\
\text { za c. kr. pješačtvo. Po } \\
\text { najnovijih izvorih. }\end{array}$ & $\begin{array}{l}\text { Zagreb, Tisak } \\
\text { dioničke tiskare }\end{array}$ & $\begin{array}{l}\text { Juraj } \\
\text { Grbačić }\end{array}$ & NSK \\
\hline 1876. & $\begin{array}{l}\text { Naputak za provedbu } \\
\text { ugarskoga zak. članka } \\
\text { XL:1866 ob obranbenoj } \\
\text { sili. (Službeno izdanje) }\end{array}$ & Zagreb & sine nomine & $\begin{array}{l}\text { NSK (sig. } \\
135.595 \text { ) }\end{array}$ \\
\hline 1877. & $\begin{array}{l}\text { Propis ob odjevanju } \\
\text { i opravljanju kr. ug. } \\
\text { domobranstvo (Uredovno } \\
\text { izdanje) }\end{array}$ & $\begin{array}{l}\text { Zagreb, tiskom } \\
\text { Lav. Hartmana i } \\
\text { družbe }\end{array}$ & sine nomine & NSK \\
\hline 1877. & $\begin{array}{l}\text { Izvadak iz Službovnika za } \\
\text { novake carsko-kraljevske } \\
\text { mornarice }\end{array}$ & $\begin{array}{l}\text { Pula, tiskom G. } \\
\text { Seražina }\end{array}$ & sine nomine & google books \\
\hline 1877. & $\begin{array}{l}\text { Pouka o napravi, } \\
\text { postupanju, uzdržavanju } \\
\text { pregledanju i porabi } \\
\text { oružničke puške- } \\
\text { opetovače Fruwirthova } \\
\text { sustava, zatim o strijeljivu } \\
\text { njoj namijenjenom }\end{array}$ & Zagreb & sine nomine & NSK \\
\hline
\end{tabular}

\section{Izvori}

Domobranski žepnik za kr. hrv.-ugarsko domobransko pješačtvo. U pitanjah i odgovorih. 1871. Tiskom narodne tiskarne dra. Ljudevita Gaja. Zagreb.

Izvadak iz Službovnika ces. kralj. pješačtva. 1868. Tiskom A. Jakića. Zagreb.

Izvadak iz Službovnika ces. kralj. pješačtva. 1868. Drugo izdanje. Tiskom A. Jakića. Zagreb.

Izvadak iz Službovnika ces. kr. vojske namienjen službenicima nižim od vôdnika. 1874. Tiskom Dioničke tiskare. Zagreb. 
Naredbenik za kraljevsko hrvatsko-ugarsko domobranstvo. 1870. - 1873. Sv. 1.-15. Tiskom narodne tiskare dra. Ljudevita Gaja. Zagreb.

Nova ratna služba c. kr. vojske za podčastnike i momčadske učione. 1871. Brzotiskom I. Vončine. Vojni Sisak.

Obučevnik ces. kralj. pješačtva. 1871. Brzotiskom I. Vončine. Vojni Sisak.

Obučevnik za kr. ugarsko domobransko konjaničtvo (Službeno izdanje). 1873. Tiskom narodne tiskare dra. Ljudevita Gaja. Zagreb.

Obučevnik za kraljevsko-ugarske domobranske sipačarske odjele (Službeno izdanje). 1874. Tiskom narodne tiskare dra. Ljudevita Gaja. Zagreb.

Pouka o pucanju za sipačarske odjele kr. ug. domobrani. 1874. Tiskom narodne tiskare dra. Ljudevita Gaja. Zagreb.

Pouka o uredbi, čuvanju, pregledavanju i postupanju puškom po Waenzlovom sustavu preradjenom i o njezinu strjelivu. 1871. Brzotiskom I. Vončine. Vojni Sisak.

Pouka o ustrojstvu čistitbi, pregledbi, čuvanju i postupanju puške: po Waenzlovom sustavu prepravljene i o njezinu streljivu. 1868. Brzotiskom Antuna Jakića. Zagreb.

Službovnik za kr. hrvatsko-ugarsko domobranstvo. I. dio. 1875. Tiskom L. Hartmana i družbe. Zagreb.

Službovnik za kr. hrvatsko-ugarsko domobranstvo. I. dio. Drugo izdanje Službovnika od godine 1875. 1887. Pallas. Budimpešta.

Ustrojne ustanove za opremljenu ugarsko-austrijsku vojsku. Prvi diel: Ustrojben propisnik. 1873. Prevedeno po nalogu kr. ugarskoga popečiteljstva za obranu zemlje. Tiskom narodne tiskare dra. Ljudevita Gaja. Zagreb.

Ustrojne ustanove za opremljenu ugarsko-austrijsku vojsku. Drugi diel: Poslovnik za viša zapovjedničtva i stožere podignute vojske. 1875. Prevedeno po nalogu kr. ugarskoga popečiteljstva za obranu zemlje. Tiskom narodne tiskare dra. Ljudevita Gaja. Zagreb.

Vježbovnik za kr. ugarsko domobransko konjaništvo. 1873. Zagreb.

\section{Literatura}

GostL, IGOR. 1996. Bogoslav Šulek, otac hrvatskoga znanstvenoga nazivlja. Radovi Leksikografskoga zavoda Miroslav Krleža 5. 9-58.

Grba, Radovan; Tomičić, Ivan. 1908. Za kralja i dom: slike, životopisi i crtice 230 hrvatskih generala / prema sastavcima Njih. Preuzvišenosti gospodina podmaršala Rade Gerbe, zapovjednika c. i kr. vojnog zbora i zapovjedajućeg generala u Zagrebu, te podmaršala u m. Ivana Viteza Tomičića od Gorice, u Beču. Tisak i naklada knjižare Lav. Weissa. Bjelovar. 
HAM, SANDA. 2016. Hrvatsko domobransko nazivlje. Jezik: Časopis za kulturu hrvatskoga književnog jezika 63/4-5. 126-40.

HAM, SANDA. 2017. Hrvatsko domobransko nazivlje. Jezik: Časopis za kulturu hrvatskoga književnog jezika 64/2. 52-55.

Horel, Catherine. 2015. Vojnici između nacionalnih fronti: ukidanje Vojne krajine $i$ razvoj Kraljevskoga ugarskog domobranstva u Hrvatskoj i Slavoniji 1868. - 1914. Filozofski fakultet Sveučilišta u Zagrebu. Zagreb.

Horvat, Marijana, Hudeček, Lana; Mihaljević, Milica. 2015. Jezik hrvatskih znanstvenih tekstova u 19. stoljeću. Povijest hrvatskoga jezika. 4. knjiga: 19. stoljeće. Gl. ur. Bičanić, Ante. Croatica. Zagreb. 301-355.

Horvat, Marijana; Minaljević Milica. 2019. Život i djelo Bogoslava Šuleka. Zadarska smotra: Časopis za kulturu znanost i umjetnost LXVIII/1-3. 46-62.

Horvatić, Ivica. 1995. Nova terminologija u Hrvatskoj vojsci. Prevođenje-suvremena strujanja i tendencije: zbornik radova. Ur. Mihaljević Djigunović, Jelena; Pintarić, Neda. Hrvatsko društvo za primijenjenu lingvistiku. Zagreb. 273-280.

Hudeček, Lana; Minaljević, Milica. 2019. Kako normativnu preporuku donosi terminolog, a kako standardolog? Ur. Matešić, Mihaela; Vlastelić, Anastazija. Zbornik radova s međunarodnoga znanstvenog skupa Hrvatskoga društva za primijenjenu lingvistiku održanoga od 3. do 5. svibnja 2018. Jezik i um. Srednja Europa. Zagreb. 3-30.

Katičić, Radoslav. 1999. Načela standardnosti hrvatskoga jezika. Norme i normiranje hrvatskoga standardnoga jezika. Ur. Samardžija, Marko. Matica hrvatska. Zagreb. 295-307.

Maixner, Rudolf; Esin, Ivan. 1952. Bibliografija radova dra. Bogoslava Šuleka. Bogoslav Šulek: Izabrani članci. JAZU. Zagreb.

Mamić, Mile. 2007. Hrvatsko vojno nazivlje u rječniku Juridisch-politische Terminologie. Jezik: Časopis za kulturu hrvatskoga književnog jezika 54/2. 55-60.

Mamić, MiLe. 2008. Hrvatsko vojno nazivlje u rječniku Juridisch-politische Terminologie. Babićev zbornik o 80. obljetnici života. Ur. Mirković, Slavko. Ogranak Matice hrvatske Slavonski Brod. Slavonski Brod.

MARTINČIĆ, IVAN. 2020. Šulekijana i šulekizmi u šulekografiji i hrvatskoj leksikografiji. Hrvatska sveučilišna naklada. Zagreb.

OrešKOvić, Zvonko. 2010. Die zeitgenössische Kroatische Militärterminologie und die Geschichte ihrer Entstehung. Doktorski rad. Historisch-Kulturwissenschaftliche Fakultät. Wien. 400 str. doi.org/10.25365/thesis.8614.

Pranjković, Ivo. 2006. Filološki vjekopisi. Disput. Zagreb.

SAMARDŽIJA, MARKo. 2004. Iz triju stoljeća hrvatskoga standardnog jezika. Hrvatska sveučilišna naklada. Zagreb. 
SAmardžIJA, Marko. 2008. Hrvatski jezik, pravopis i jezična politika Nezavisnoj Državi Hrvatskoj. Hrvatska sveučilišna naklada. Zagreb.

SAmARDŽIJA, Marko. 2019. Hrvatska leksikografija. Od početaka do kraja XX. stoljeća. Matica hrvatska. Zagreb.

Schmidt-Brentano, Antonio. 2007. Die k. k. bzw. k. u. k. Generalität: 1816-1918. Österreichischen Staatsarchiv. Wien.

Svoboda, Johann. 1894. Die Theresianische Militär-Akademie zu Wiener-Neustad : und ihre Zöglinge von der Gründung der Anstalt bis auf unsere Tage. Zweiter Band. Kaiserlich-königlichen Hof- und Staatsdruckerei. Wien.

Tominac, Nikola. 2004. Stajnica i okolica. Zavičajni klub Stajnica. Zagreb.

TORBAR, Josip. 1896. Nekrolog: O životu i djelovanju dra. Bogoslava Šuleka. Ljetopis JAZU 11. 101-93.

VIENAC = Vienac, Zabavi i pouci br. 43 (1871.), br. 32 (1874.), br. 40 (1875.), br. 9 (1876.).

Vince, Zlatko. ${ }^{2}$ 1990. Putovima hrvatskoga književnog jezika. Lingvističko-kulturnopovijesni prikaz filoloških škola i njihovih izbora. Nakladni zavod Matice hrvatske. Zagreb.

VraneŠa, Ana; Petrović, Bernardina. 2016. Primjenjivost Šulekovih metodoloških načela na usustavljivanje hrvatskoga nazivlja molekularne i stanične biologije. Bogoslav Šulek a jeho filologické dilo / i njegov filološki rad. Kolektivni monografie. Ur. Krejči, Pavel; Krejčová, Elena. Česká asociace slavistů - Ústav slavistiky FF MU. Brno.

VRGOČ, DALIBOR. 2020a. Terminološki aspekti stvaranja hrvatskoga vojnog nazivlja. Doktorski rad. Filozofski fakultet Sveučilišta u Zagrebu. Zagreb. 420 str. doi. org/10.17234/diss.2020.8543.

VRgoč, Dalibor. 2020b. Ivan (Giovanni) Tanzlingher Zanotti - praotac hrvatskoga vojnog nazivlja. Ricerche Slavistiche 3/LXIII. 405-447.

VRGOČ, DALIBOR. 2021a. Hrvatsko vojno nazivlje u predšulekovskim vojnim priručnicima. Zbornik radova sa Sedmoga hrvatskog slavističkog kongresa (u tisku). Ur. Baković, Ivica; Frančić, Anđela; Malnar Jurišić, Marija; Molvarec, Lana; Petrović, Bernardina. Hrvatsko filološko društvo. Zagreb.

VRGOČ, DALiBOR. 2021b. Tko je bio hrvatski krajiški časnik S. S. K.? Vojna krajina u suvremenoj historiografiji (u pripremi). Ur. Roksandić, Drago; Muić, Vedran. Filozofski fakultet Sveučilišta u Zagrebu, Centar za komparativnohistorijske i interkulturne studije i FF press. Zagreb. 


\section{Croatian Home Guard Officers Elite - Co-Creators of Military Terminology}

\section{Abstract}

The paper examines the current scholarly insights about the beginnings of the official development of Croatian military terminology from the second half of the $19^{\text {th }}$ century, primarily about the uniqueness of the role of Bogoslav Šulek as its founder. The research of primary sources proves that Šulek - although a pivotal figure in military terminography efforts - was not the only creator of the Croatian military lexis. By studying the archives in Zagreb and Vienna, a number of authors came to light, who translated military manuals into Croatian amid the dynamic establishment of the Croatian Home Guard. Moreover, in addition to numerous military literature titles, they also published two pioneering military-language manuals. The authors belonged to the Home Guard officer's teaching staff, so Šulek stood as the only non-military person among them. The new configuration of those responsible for the establishment of Croatian military terminology reveals how some important titles have so far been wrongly attributed to Šulek, but also points to new insights into the scope of Šulek's opus and the availability of his titles. The comparison of officers' translations with those of Bogoslav Šulek completes the mosaic of the linguistic conception of the construction of Croatian military terminology.

Ključne riječi: hrvatsko vojno nazivlje, Bogoslav Šulek, Ivan Vuković, Stjepan pl. Šašić Kirinski, Kraljevsko hrvatsko domobranstvo, Službovnik za ugarsko-hrvatsko domobranstvo Keywords: Croatian military terminology, Bogoslav Šulek, Ivan Vuković, Stjepan pl. Šašić Kirinski, Royal Croatian Home Guard, Službovnik za ugarsko-hrvatsko domobranstvo 